\title{
PILKADA SERENTAK DAN GELIAT DINAMIKA POLITIK DAN PEMERINTAHAN LOKAL INDONESIA
}

\author{
Idil Akbar \\ Program Studi Ilmu Pemerintahan Fakultas Ilmu Sosial \\ dan Ilmu Politik (FISIP)Universitas Padjadjaran \\ Email: idil.akbar@ unpad.ac.id
}

\begin{abstract}
ABSTRAK
Pemilihan Kepala Daerah (Pilkada) Serentak menjadi arena baru bagi rakyat Indonesia. Bukan hanya pada persoalan berbeda waktu pelaksanaan, sistem pelaksanaan, prosedur dan mekanisme pemilihannya, tetapi juga tetapi juga soal, yang oleh Brian C. Smith dan Robert Dahl katakan adalah untuk menciptakan local accountability, political equity dan local responsiveness. Pilkada serentak karenanya berupaya membangun demokratisasi di tingkat lokal agar terimplementasikan dengan baik, tak hanya terkait pada tingkat partisipasi, tetapi juga relasi kuasa yang dibangun, yang bersumber dari pelaksanaan azas kedaulatan rakyat. Selain itu, hasil pilkada juga harus mampu menghantarkan masyarakat pada kondisi sosial, politik dan ekonomi yang lebih baik.

Penelitian yang di lakukan ini menggunakan metode penelitian dengan metode kualitatif refleksif, yaitu ingin merefleksikan tentang pilkada serentak dan kaitannya terhadap upaya membangun geliat demokrasi dalam pemerintahan dan politik lokal serta menjamin hadirnya kemaslahatan bersama dalam masyarakat. Data diperoleh melalui studi literatur melalui kepustakaan, dokumen dan pemberitaandi media massa.

Diperoleh hasil bahwa mengimplementasikan demokrasi dalam politik lokal tidaklah mudah. Sebab, konteks demokratisasi tidak hanya berhenti pada tahapan prosedural semata. Jauh lebih dari itu adalah bagaimana membumikan demokrasi dalam aras yang substansial. Membangun partisipasi rakyat misalnya, membut uhkan komitmen kuat agar bisa menjamin setiap warga negara bisa berpatisipasi secara baik. Selain itu, jika demokrasi dinilai sebagai cara untuk mencapai kesejahteraan bersama secara lebih luas, maka pilkada sebagai perwujudan dari demokrasi prosedural berperan penting untuk menjaga kualitas kepemimpinan lokal, memberikan garansi terhadap keberlanjut an pemerint ahan yang nantinya dijalankan serta secara kontekstual mampu membangun sinergitas korelasional antara
\end{abstract}


pemimpin dengan rakyat yang dipimpin. Hal ini dikarenakan pilkada pada dasarnya berorientasi untuk memberi nilai atas pilkada terhadap kemaslahatan dan kepentingan rakyat.

Kata Kunci: Pilkada Serentak, Demokrasi dan Demokratisasi, Partisipasi, Politik dan Pemerintahan Lokal

\section{ABSTRACT}

The simoultan election of district head nowadays has become a new arena for all Indonesian people. It is not only about the difference of time, system, procedures and mechanism in its activity but also about, which said by Brian C. Smith and Robert Dahl are for implement local accountability, political equity and local responsiveness. Hence, it is trying to develop local democratization for that it can be implemented well, not only in participation level but also in power relation, which resulted from implementation of the principle of people sovereignty. Besides that, the result of the election of district head must able to delivering the peoples to social, political and economic situation much better.

This research did by qualitative reflective method, that is try to reflection about the simoultan election of district head and its relation to developing stretching democracy in government and local politics, and to guaranteeing the presence of the common good in society. The data got by literature study.

The result shown to implementation of democracy in government and local politics are not easy. Because, democratization not only stag in procedure step, more than that but also how to unearth democracy in a state of substantial. Developing of people participation, for example, need the strong commitment in order to guarantee all citizens could be participated well. Besides that, if democracy rated as the path for reach the common wealth, so the election of district head has important role to guard quality of local leadership, to guarantee the ruling govern and to develop synergy among the leader and their peoples. It is because the election of district head has orientation to bring values for common good in society and for society interest.

Keywords: The simoultan election of district head, democracy and democratization, participation, government and local politics. 


\section{PENDAHULUAN}

Pemilihan Kepala Daerah (Pilkada) serentak telah usai dilaksanakan 9 Desember 2015 lalu. Tak kurang dari 264 daerah, yang terdiri dari 9 provinsi, 34 kota dan 224 kabupaten ${ }^{62}$ minus Provinsi Kalimantan Tengah, Kabupaten Fakfak, Kota Pemantangsiantar, Kabupaten Simalungun, dan Kota Manado karena mengalami penundaan hingga 2017, telah menyelenggarakan pilkada secara serentak. Era baru dalam sistem pemilihan, yang tentu bukan hanya soal waktu pelaksanaan, tetapi juga soal, yang oleh Brian C. Smith dan Robert Dahl, adalah untuk menciptakan local accountability, political equity dan local responsiveness (Suara KPU, edisi II-2015: 4), khususnya untuk melihat sejauh mana rakyat di daerah bisa menentukan sendiri nasib, pemimpin dan pemerintahannya.

Dalam konteks demokrasi, dinamika politik dan pemerintahan lokal seperti ini akan menentukan bagaimana wajah demokrasi Indonesia secara nasional. Karena itu, pilkada serentak juga merupakan akses bagi masyarakat untuk berpatisipasi lebih luas, menghimpun banyak kepercayaan terhadap calon kandidat.
Dengan kata lain, penekanan kadar demokrasi pada suatu pemilihan juga ditentukan oleh seberapa besar peranan masyarakat dalam menentukan siapa diantara mereka yang dipercaya dan layak untuk memimpin. Karena itu sebagai cerminan, maka tak salah jika Robert Dahl mengatakan, demokratisasi di tingkat nasional hanya terbangun jika demokrasi berlangsung pada tingkat lokal ${ }^{63}$ (Gill, 1995: 6-7).

Partisipasi rakyat menjadi indikator cukup penting untuk menggambarkan bagaimana kesuksesan penyelenggaraan sebuah pemilihan. Meski, tinggi rendahnya partisipasi rakyat dalam pemilihan tak selalu berkorelasi secara linier dengan kualitas pemilihan itu sendiri. Kualitas yang lebih menyandarkan pada upaya untuk memberi pemahaman tentang pemilihan melalui pendidikan politik, sosialisasi dan komunikasi serta artikulasi dan agregasi merupakan bagian penting dari penyelenggaraan pemilihan yang berkualitas.

Jika pun banyak ilmuwan politik menganggap penting tingginya partisipasi masyarakat dalam sebuah pemilihan itu dilandaskan pada keberhargaan (value) suara rakyat bagi negara dan pemerintahan.

62. Diakses dari http://www.kpu.go.id/index.php/post/read/2015/4101/810-Pasangan-Calontelah-Terdaftar-dalam-Pilkada-Serentak-2015, tanggal 1 Februari 2016, pukul 21.10 WIB.

63. Guy S. Good-Gill, Pemilu Jurdil: Pengalaman dan Standar Internasional, PIRAC \& The Asia Foundation, Jakarta, 1995, hal.6-7. 
Korelasi dari tingkat partisipasi rakyat adalah dalam kerangka memberi pengaruh terhadap legitimasi. Banyak kalangan menilai, semakin tinggi tingkat partisipasi akan memberi pengaruh positif terhadap tingkat legitimasi pemerintahan yang dijalankan. Karenanya, partisipasi dianggap sebagai bagian dari legitimasi pemerintahan disebabkan dari suara yang disampaikan oleh setiap warga negara dalam pemilihan.

Dalam konteks partisipasi, keikutsertaan masyarakat dalam pilkada serentak tak cukup menggembirakan. Artinya, masih banyak daerah yang tingkat partisipasi politik masyarakat masih tergolong rendah. Tercatat, partisipasi politik masyarakat tertinggi terjadi di Kabupaten Mamuju Tengah (92,17 persen), sementara terendah terjadi di Kota Medan (26,88 persen). Dengan demikian, tingkat partisipasi pemilih secara umum hanya sekitar 64,23 persen atau lebih rendah daripada target yang dipatok oleh KPU, yakni sekitar 75,5 persen ${ }^{64}$. Tetapi tetap saja rendahnya tingkat partisipasi tidak menentukan hasil pilkada.

Pilkada mencerminkan adanya pelibatan masyarakat dalam sebuah proses politik di daerah. Cerminan terhadap pelibatan tersebut menyaratkan penyelenggaraan pilkada yang demokratis sebagai syarat penting dalam pembentukan kepemimpinan dalam sebuah daerah. Sebab, pilkada adalah proses yang menjadi bagian dari legitimasi kekuasaan. Menurut V. O Key, pemilih akan menetapkan pilihannya dengan cara memberi penilaian terhadap kinerja kandidat. Pemilih akan menilai apakah calon memiliki kapasitas, kapabilitas dan kinerja yang baik atau belum bagi dirinya sendiri ataupun bagi daerah. Pemilih juga akan menilai kapabilitas sosok calon tersebut apabila ia dibandingkan dengan sosok pemimpin dari pemerintahan-pemerintahan sebelumnya ${ }^{65}$.

Dengan logika ini maka, penting melibatkan masyarakat secara luas dalam pilkada dengan tetap terus meningkatkan kualitas penyelenggaraan pilkada itu sendiri. Pilkada juga menjadi refleksi didalam melihat bagaimana geliat dinamika politik dan pemerintahan lokal. Sebab melalui pilkada, masyarakat akan memiliki kepala daerah definitif yang dalam kapasitas dan kewenangannya akan menentukan masa depan daerah tersebut dalam lima tahun mendatang.

\footnotetext{
64. Diakses dari http://www.bawaslu-dki.go.id/14/12/2015/menyoal-partisipasi-pemilihpilkada/, tanggal 1 Februari 2016, pukul 21.20 WIB.

65. Ibid
} 
Menilai bagaimana dinamika politik dan pemerintahan lokal berjalan dalam pilkada serentak dapat dilihat dari dua aspek, pertama, sejauhmana demokratisasi di tingkat lokal terimplementasikan dengan baik, tak hanya terkait pada tingkat partisipasi, tetapi juga relasi kuasa yang dibangun, yang bersumber dari pelaksanaan azas kedaulatan rakyat. Kedua, sejauhmana hasil pilkada nantinya mampu menghantarkan masyarakat pada kondisi sosial, politik dan ekonomi yang lebih baik. Contoh sederhana dari konteks ini adalah apakah nanti para kepala daerah terpilih mampu merealisasikan janji politik yang telah disampaikan dan mampu membuka ruang/akses bagi masyarakat untuk menyampaikan tuntutan.

Kedua hal ini yang nantinya akan dibahas secara komprehensif untuk mengetahui korelasi antara pilkada serentak dengan upaya menjaga dinamika politik dan pemerintahan lokal. Diharapkan, analisis ini akan menjadi refleksi penting di dalam mengkonstruksikan pandangan yang integratif tentang usaha melakukan perbaikan-perbaikan yang lebih mendasar atas pelaksanaan pilkada serentak.

\section{LITERATUR RIVIEW}

\section{Pilkada}

Sejak tahun 2005 di Indonesia dikondisikan sebuah prosedur demokratis yang baru untuk mengganti dan mengisi jabatan Kepala Daerah, yang secara konseptual disebut "Pilkada". Dalam skenarionya dibayangkan bahwa warga masyarakat membutuhkan Pilkada. Melalui Pilkada itu penduduk di suatu daerah dapat dengan bebas merdeka mendukung seseorang untuk menjadi Kepala Daerah, sesuai dengan aspirasinya yang beragam, dan mestinya dengan rasionalitasnya masing-masing. Dalam kaitan itu setiap aktor yang menjadi kandidat dituntut harus membuat komitmen politik, sebagai tafsir lain dari pentingnya 'kontrak sosial', untuk memperjuangkan aspirasi rakyat, yang isu pokoknya biasanya tidak jauh dari persoalan kesejahteraan rakyat dan rasa keadilan $\operatorname{sosial}^{66}$.

Pilkada sebagai perhelatan politik, sejatinya merupakan sebuah panggung yang mempertunjukkan sebuah dramaturgi. Masalahnya, rakyat sebagai pemilik kedaulatan politik demokratis tidaklah membutuhkan

66. Mukhtar Sarman, Pilkada Serentak: Quo Vadis Kedaulatan Rakyat, Program Magister Sains Administrasi Pembangunan Universitas Lambung Mangkurat, Banjarmasin, 2015, hal.14. 
dramaturgi yang memposisikan mereka hanya sekadar sebagai penonton pasif. Pilkada itu diidealkan harus adil, dan asas keadilan dimaksud bukan hanya dalam kerangka tidak ada pilih kasih dari pihak penyelenggara, tetapi juga harus adil dalam memperlakukan rakyat sebagai pemegang kedaulatan ${ }^{67}$.

Pilkada sejatinya adalah menjadi sarana bagi rakyat untuk memilih pemimpin yang terbaik bagi rakyat dan daerahnya. Harapannya melalui pilkada akan lahir pemimpin daerah yang mampu memenuhi ekspektasi rakyat secara mayoritas, mempercepat pertumbuhan ekonomi daerah, meningkatkan kesejahteraan dan menjaga kedaulatan rakyat secara bermartabat. Ekspetasi rakyat ini juga menuntut perubahan besar yang terwujud dalam kebijakan-kebijakan yang pro rakyat.

\section{Demokrasi Lokal}

Dalam kamus politik, demokratisasi secara harfiah berarti the process of becoming democratic ${ }^{68}$.
Atau dengan kata lain dapat dikatakan bahwa demokratisasi merupakan perubahan dari suatu kondisi yang sebelumnya tidak demokratis menjadi demokratis.Konteksini, demokratisasi merupakan sebuah proses substansi dan terpenting dari politik etnis yang tengah mengalami transisi menuju substansi pemilu yang demokratis.

Konsep demokrasi bersifat evolutif dan dinamis, bukan konsep yang statis. Dengan begitu, konsep demokrasi selalu mengalami perubahan, baik bentuk-bentuknya maupun substansialnya sesuai dengan konteks dan dinamika sosio historis dimana konsep demokrasi lahir dan berkembang ${ }^{69}$. Dahlan Thaib mengatakan bahwa asas kedaulatan rakyat atau paham demokrasi mengandung dua arti: Pertama, demokrasi partisipatif terkait sistem pemerintahan atau lebih melihat pada bagaimana proses penyertaan rakyat dalam penyelenggaraan pemerintahan, dan yang kedua, demokrasi sebagai asas yang dipengaruhi keadaan kultural, historis satu bangsa sehingga muncul istilah demokrasi konstitusional, demokrasi rakyat dan demokrasi Pancasila ${ }^{70}$.

67. Ibid. Hal.8

78. Mc. Lean Iain, The Concise Dictionary of Politic, Axford University Press, New York, 1996, hal.133.

69. Muhammad Zulfan Hakim, Demokrasi dalam Pilkada Indonesia, artikel Jurnal, diakses dari http://repository.unhas.ac.id/bitstream/handle/123456789/4068/DEMOKRASI\%20 DALAM\%20PILKADA\%20DI\%20INDONESIA\%20\%28Jurnal\%20Humanis \%20 UNM\%29.pdf? sequence=1, tanggal 8 Februari 2015, pukul 20.10 WIB.

70. Dahlan Thaib, Kedaulatan Rakyat, Negara Hukum, dan Konstitusi, Liberty, Yogyakarta, 1999. Ibid. 
Demokrasi, menurut Dahl (1999), harus dilihat sebagai proses politik yang membuka peluang bagi partisipasi politik rakyat untuk secara efektif melakukan pengawasan terhadap agenda dan keputusan politik. Pendapat serupa juga dikemukakan Holden (1975:8), di dalam demokrasi rakyat diberikan hak membuat keputusan (dalam bentuk kebijakan publik) menyangkut masalah-masalah penting. Pendapat Dahl dan Holden sangat relevan dalam konteks demokratisasi di Indonesia baik pada tingkat nasional maupun lokal, yang memberikan peluang peranan atau partisipasi politik rakyat untuk mengawal agenda reformasi, karena, seperti dikemukakan Almond dan Nelson (1982), partisipasi politik rakyat merupakan salah satu tolok ukur penting untuk menilai apakah suatu sistem politik itu demokratik, otoriter, atau bentuk sistem politik lainnya ${ }^{71}$.

Joseph Schumpeter yang tertuang dalam bukunya Capitalism, Socialism and Democracy $(1942)^{72}$, mendeskripsikan demokrasi sebagai tatanan institusional, sebuah mekanisme dalam politik untuk mengisi jabatan politik melalui kompetisi dalam merebut dukungan rakyat. Demokrasi dalam konteks Pemilu dan Pilkada, menurut Schumpeter, menjelaskan bahwa rakyat memiliki peluang untuk menerima atau menolak orang-orang yang mencalonkan diri untuk memimpin mereka ${ }^{73}$.

Namun, dalam pandangan Schumpeter juga memberi kritik tentang demokrasi sebagai "pemerintahan oleh rakyat" (government by the people) sebagai istilah yang kurang tepat. Baginya, demokrasi lebih dipandang sebagai "pemerintahan yang disetujui oleh rakyat" (government approved by the people $)^{74}$. Hal ini menjelaskan bahwa pada dasarnya pilkada hanyalah sarana bagi rakyat untuk menyetujui sebuah pemerintahan dijalankan oleh mereka yang dipilih dalam pemilihan.

Hanya, penekanan kadar demokrasi pada suatu pemilihan juga ditentukan oleh seberapa besar peranan masyarakat dalam menentukan siapa diantara mereka yang dipercaya dan layak untuk memimpin. Pemilihan langsung karenanya dinilai berkorelasi

71. TB. Massa Djafar, Demokratisasi, DPRD dan Penguatan Politik Lokal, Jurnal Poelitik, Vol. 1, No.1 Tahun 2008, hal. 2

72. Andrey Heywood, Politics (4th edition), Palgrave Macmillan, London, 2013, dialihbahasakan oleh Ahmad Lintang Lazuardi, Politik (edisi ke-4), Pustaka Pelajar, Yogyakarta, 2014, hal.357.

73. Andrey Heywood, ibid.

74. Joseph A. Schumpeter, Capitalism, Socialism and Democracy, (Allenand Unwin, London), 1943, hal. 246. 
terhadap nilai dari demokrasi itu sendiri. Keterpilihan seorang politisi untuk tingkat nasional tentunya tak lepas dari bagaimana partisipasi masyarakat di daerah memilih secara langsung kandidat tersebut. Penting diingat pula bahwa dalam konsep demokrasi lokal, Stocker menjelaskan bahwa bangunan demokrasi di tingkat lokal akan menopang kuatnya demokrasi di tingkat nasional. Sebab, demokrasi lokal merupakan bagian penting bagi demokrasi nasional ${ }^{75}$.

\section{METODE PENELITIAN}

Penelitian yang di lakukan ini menggunakan metode penelitian dengan metode kualitatif refleksif. Penelitian refleksif digunakan oleh peneliti sosial untuk menjelaskan bagaimana fakta atau realitas sosial dikonstruksikan - bukan direpresentasikan. Penelitian refleksif bersumber dari pandangan Ulrich Beck dalam Risk Society (1992). Beck membahas mengenai modernitas refleksif. Refleksif adalah konfrontasi diri (self confrontation). Ketika ada suatu fenomena sosial, manusia harus menghadapinya dan harus berpikir mengenai hal itu. Dengan konfrontasi diri, manusia dapat mengikuti dengan baik dinamika sosial yang terjadi. Sebab, dinamika sosial ini tidak hanya terjadi secara manifes, tetapi juga laten alias tidak tampak dan tidak terduga. Dengan berpikir refleksif, masyarakat modern dapat memahami hal-hal yang terkadang tidak dapat dipahami dengan logika pemikiran dan pengetahuan modern.

Dalam penelitian refleksif, menurut Woolgar, para ilmuwan sosial didorong untuk merefleksikan situasi sosial dalam pengetahuan mereka. Refleksivitas adalah sesuatu yang timbul atau merupakan hasil reaksi dari ilmu sosial yang sering merelatifkan semua kecenderungan. Menurut Mats Alvesson dan Kaj Skoldberg, refleksivitas adalah penaksiran total antara "pengetahuan" dan "bagaimana pengetahuan bekerja". Konsep refleksif ini mengeksplorasi lebih mendalam aspek-aspek linguistik, sosial, politik dan elemen teoritis. Semua aspekaspek ini dijalin bersama dan dilihat bagaimana ini semua dikonstruksikan, diinterpretasikandan ditulis ${ }^{76}$.

75. Gerry Stoker, The Politics of Local Government ( $2^{\text {nd }}$ edition), London, Mcmillan, 1991, hal.303

76. Mats, Skoldberg dan Kaj Alvesson, Reflexive Methodology, Thousand Oaks, London, Sage Publication, New Delhi, 2000, hal.5 
Dengan kata lain, penelitian ini ingin merefleksikan tentang pilkada serentak dan kaitannya terhadap upaya membangun geliat demokrasi dalam pemerintahan dan politik lokal serta menjamin hadirnya kemaslahatan bersama dalam masyarakat. Sementara data diperoleh melalui studi literatur melalui kepustakaan, dokumen dan pemberitaandi media massa.

\section{HASIL DAN PEMBAHASAN}

\section{Implementasi Demokrasi dalam Politik Lokal}

Sejauhmana demokratisasi di tingkat lokal terimplementasikan dengan baik, tak hanya terkait pada tingkat partisipasi, tetapi juga relasi kuasa yang dibangun, yang bersumber dari pelaksanaan azas kedaulatan rakyat. Jika menilik secara kontekstual, sudahkah pilkada secara nyata menjalankan prinsip dari kedaulatan tersebut? Jika kedaulatan rakyat dinilai sebagai proses dari pelimpahan kekuasaan untuk menjalankan kewenangan, maka pilkada wajib melibatkan rakyat secara langsung.
Dalam konsep demokrasi minimalis (Polyarchy) Robert A. Dahl, setidaknya pilkada mencakup dua dimensi utama, yakni kontestasi dan partisipasi. Kontestasi berarti mengukur seberapa tinggi tingkat kontestasi, kompetisi atau oposisi yang memungkin. Sedangkan partisipasi mengukur seberapa banyak warga negara bisa memperoleh kesempatan berpartisipasi dalam kompetisi politik itu $^{77}$.

Lebih jauh, Dahl menyampaikan tujuh indikator dari sistem yang demokratis, yaitu ${ }^{78}$ :

1. Kontrol pada pembuat kebijakan dilakukan oleh pejabat publik yang terpilih

2. Pemilihan pejabat publik diselenggarakan melalui pemilu yang teratur, fair dan bebas.

3. Setiap warga negara mempunyai persamaan hak memitih dalam pemilu

4. Setiap warga negera mempunyai persamaan hak untuk dipilih dalam pemilu

5. Jaminan kebebasan dasar dan politik;

6. Adanya saluran informasi alternatif yang tidak dimonopoli

77. Robert A. Dahl, Polyarchy: Opposition and Participation, Yale University Press, New Haven and London. 1971. Hal. 228-230.

78. http://elisa.ugm.ac.id/user/archive/download/32057/1 eca8113b2304776be65f882f93e9009, diakses tanggal 8 April 2016, pukul 21.10 WIB. 
pemerintah atau kelompok tertentu.

7. Adanya jaminan untuk membentuk dan bergabung pada organisasi, termasuk partai politik dan kelompok kepentingan.

Diamond, Linz dan Lipset termasukyang merumuskan demokrasi sebagai suatu sistem pemerintahan yang memenuhi tiga syarat pokok, yakni $^{79}$ :

1. Kompetisi yang sungguh-sungguh dan meluas diantara individuindividu dan kelompok-kelompok organisasi (terutama partai politik) untuk memperebutkan jabatan-jabatan pemerintahan yang mempunyai kekuasaan efektif, pada jangka waktu yang reguler dan tidak melibatkan penggunaan daya paksa;

2. Partisipasi politik yang melibatkan sebanyak mungkin warga dalam pemilihan pemimpin atau kebijakan, paling tidak melalui pemilihan umum yang dislenggarakan secara reguler dan adil, sedemikian rupa sehingga tidak satupun kelompok yang dikecualikan.

3. Kebebasan sipil dan politik; kebebasan berbicara, kebebasan pers, kebebasan untuk membentuk dan bergabung ke dalam organisasi, yang cukup menjamin integritas kompetisi dan partisipasi politik.

Pengamatan terhadap demokratisasi di tingkat lokal sebetulnya lebih mengarah pada bagaimana setiap orang menjalankan prinsip-prinsip berdemokrasi secara baik dalam setiap proses politik yang dilakukan. Arahan utamanya adalah menjadikan rakyat sebagai subjek politik yang sejatinya merupakan pemilik tertinggi dari kekuasaan. Penerapan nilai-nilai demokrasi di tingkat lokal akan menjadikan rakyat lokal belajar mengenal keinginan dan harapannya. Itulah mengapa, demokratisasi menjadi langkah penting di dalam membentuk karakteristik keadaban dan kemartabatan. Setidaknya meyakini lebih dahulu bahwa nilai-nilai demokratis perlu ditanamkan dalam diri masyarakat lokal.

Demokratisasi karenanya harus dipandang sebagai transformasi nilainilai demokratis dan bukan hanya perkara perlembagaan atau perundangan yang bersifat statik. Ini berarti demokrasi dipahami sebagai nilainilai yang diperjuangkan oleh kelompok masyarakat untuk mengatur arah penyelenggaraan pemerintahan yang demokratik bahwa demokrasi akan membangkitkan potensi masyarakat

79. Ibid. 
lokal. Riswandha (2002:46) berpendapat bahwa demokratisasi juga membawa pengaruh pada penguatan dan pengembangan masyarakat lokal, terutama dalam aspek pendidikan politik, pelatihan kepemimpinan politik, peningkatan rasa tanggungjawab, mempengaruhi kebijakan, dan meningkatkan kemampuan pemerintah melayani keinginan rakyat ${ }^{80}$.

Mengimplementasikan demokrasi dalam politik lokal tidaklah mudah. Sebab, konteks demokratisasi tidak hanya berhenti pada tahapan prosedural semata. Jauh lebih dari itu adalah bagaimana membumikan demokrasi dalam aras yang substansial. Jika pemilu dan juga pilkada disebuat sebagai perwujudan demokrasi prosedural, yang mana setiap warga negara berhak memilih dan/atau dipilih, maka perwujudan demokrasi substansial adalah bagaimana membawa setiap warga negara memahami haknya dengan baik dan benar.

Pertanyaannya, bagaimana rakyat sebagai subjek kekuasaan mampu mengimplementasikan demokrasi substansial dengan benar, adakah peluang untuk itu dan secara sadar bisa dilakukan? Sudahkah para pihak yang berkepentingan terhadap rakyat menjalankan fungsi politik secara komprehensif dan terintegratif, sehingga rakyat memahami sepenuhnya tentang nilai-nilai demokrasi itu sendiri?

Salah satu bentuk utama dalam demokrasi adalah adanya partisipasi politik. Partisipasi politik adalah cara bagi setiap warga negara unt uk terlibat dalam proses politik negara. Miriam Budiardjo (1994) menyatakan bahwa partisipasi merupakan kegiatan individu atau kelompok secara aktif dalam kehidupan politik, memilih pimpinan negara dan terlibat dalam mempengaruhi kebijakan publik. Hal ini juga berarti memberi penegasan penting bahwa partisipasi adalah akses bagi rakyat untuk menentukan apa yang terbaik untuk dirinya sendiri melalui jalan demokrasi.

Partisipasi politikjuga mengarahkan pergerakan penting rakyat terhadap dinamika politik yang terjadi. Sebuah pergerakan yang tidak hanya dalam kapasitas memberi pengaruh pada kebijakan publik, tetapi juga menjalankan fungsi-fungsi lain seperti pengawasan (kontrol) politik, sebagaimana Dahlmemandang demokrasi harus dilihat sebagai proses politik yang membuka peluang bagi partisipasi politik rakyat untuk secara efektif melakukan pengawasan ter-

80. TB. Massa Djafar, op.cit, hal.6-7 
hadap agenda dan keputusan politik ${ }^{81}$. Pendapat serupa juga dikemukakan Holden (1975:8) yang menyatakan bahwa di dalam demokrasi rakyat diberikan hak membuat keputusan (dalam bentuk kebijakan publik) menyangkut masalah-masalah penting 82 .

Partisipasi politik yang meluas merupakan ciri khas dari modernisasi politik. Menurut Huntington dan Nelson, partisipasi adalah kegiatan warga Negara yang bertindak sebagai pribadi-pribadi, yang dimaksud untuk mempengaruhi pembuatan keputusan oleh Pemerintah. Partisipasi bisa bersifat individual atau kolektif, terorganisir atau spontan, mantap atau sporadik, secara damai atau dengan kekerasan, legal atau illegal, efektif atau tidak efektif ${ }^{83}$.

Konsepsi partisipasi politik ini dalam pandangan Huntington dan Nelson mencakup lima hal penting ${ }^{84}$. Pertama, partisipasi politik hanyalah mencakup kegiatan-kegiatan dan bukan sikap-sikap. Dalam hal ini, mereka tidak memasukkan komponenkomponen subjektif seperti pengetahuan tentang politik, keefektifan politik, tetapi yang lebih ditekankan adalah bagaimana berbagai sikap dan perasaan tersebut berkaitan dengan bentuk tindakan politik. Kedua, yang dimaksud dengan partisipasi politik adalah warga negara biasa, bukan pejabat-pejabat pemerintah. Hal ini didasarkan pada pejabat-pejabat yang mempunyai pekerjaan profesional di bidang itu, padahal justru kajian ini pada warga negara biasa.

Ketiga, kegiatan politik adalah kegiatan yang dimaksud untuk mempengaruhi keputusan pemerintah. Kegiatan yang dimaksudkan misalnya membujuk atau menekan pejabat pemerintah untuk bertindak dengan cara-caratertent uuntukmenggagalkan keputusan, bahkan dengan cara mengubah aspek-aspek sistem politik. Dengan itu protes-protes, demonstrasi, kekerasan bahkan bentuk kekerasan pemberontak untuk mempengaruhi kebijakan pemerintah dapat disebut sebagai partisipasi politik. Keempat, partisipasi juga mencakup semua kegiatan yang mempengaruhi pemerintah, terlepas tindakan itu efektif atau tidak, berhasil at au gagal. Kelima, partisipasi politik dilakukan langsung atau tidak langsung, artinya langsung

81. Robert Dahl, Perihal Demokrasi: Menjelajahi Teori dan Praktek Demokrasi Secara Singkat, Yayasan Obor, Jakarta, 1999.

82. TB. Massa Djafar, op.cit, hal.2

83. Samuel P Huntington dan Joan Nelson, Partisipasi Politik di Negara Berkembang, Rineka Cipta, Jakarta, 1994. Hal. 4

84. Ibid. 
oleh pelakunya sendiri tanpa menggunakan perantara, tetapi ada pula yang tidak langsung melalui orangorang yang dianggap dapat menyalurkan ke pemerintah.

Hanya, dalam implementasi demokrasi di tingkat lokal, pada umumnya partisipasi politik seringkali hanya dianggap sebagai pelengkap perhelatan. Partisipasi rakyat hanya menjadi tolak ukur di dalam menjaga kontinyuitas pemerintahan sekaligus penanda berhasil tidaknya penyelenggaraan pemilihan. Kiranya partisipasi politik belum sampai pada upaya mengidentifikasi pelaksanaan kedaulatan.

Partisipasi juga kerapkali identik dengan mobilisasi dan "pesta politik". Orientasi partisipasi khususnya dalam pandangan partai politik dan calon kepala daerah hanyalah berupa perolehan dukungan sebanyak mungkin. Relasi kuasa yang dibangun pun lebih menitikberatkan pada usaha memen angkan pilkada dengan perolehan suara terbesar. Karenanya, problem demokratisasi di tingkat lokal bukan lah terletak pada ketidaktahuan akan isu-isu demokrasi, alih-alih menjadi jalan bagi upaya peningkatan kesejahteraan bersama. Tetapi, upaya pembiaran oleh stakeholders juga memberi andil besar demokratisasi berjalan stagnan.

\section{Pilkada dan Kemaslahatan Bagi Rakyat}

Tujuan utama pilkada adalah rakyat daerah bisa menentukan sendiri orang tertentu yang dianggap atau dinilai mampu membawa kebaikan bagi seluruh rakyat di daerah tersebut. Fokus penting yang terbangun adalah kesadaran politik rakyat daerah untuk bisa menentukan masa depan daerahnya sendiri melalui pemilihan kepala daerah yang tepat untuk memimpin daerah. Tentu saja, rasionalisasi sangat berperan penting agar antara rakyat sebagai pemegang kedaulatan dengan kandidat yang nantinya dipercaya bisa bersinergi untuk membangun daerahnya lebih baik.

Jika demokrasi dinilai sebagai cara untuk mencapai kesejahteraan bersama secara lebih luas, maka pilkada sebagai perwujudan dari demokrasi prosedural berperan penting untuk menjaga kualitas kepemimpinan lokal, memberikan garansi terhadap keberlanjutan pemerintahan yang nantinya dijalankan serta secara kontekstual mampu membangun sinergitas korelasional antara pemimpin dengan rakyat yang dipimpin. Mengapa ini semua perlu dipahami lebih dulu? Sebab, pilkada bagaimanapun orientasi dasarnya adalah harus memberi nilai atas pelaksanaannya dan hasilnya terhadap kemaslahatan dan kepentingan rakyat. 
Soal kemaslahatan rakyat ini sepertinya memang lebih mudah diucapkan tapi sukar untuk diwujudkan. Kecenderungan yang ada sering membawa rakyat pada realitas dilematis, yaitu kenyataan bahwa pemimpin yang dipercaya harus dirasa berubah sikap setelah mendapatkan posisi politik di pemerintahan. Hal ini disebabkan pilkada hanya (cenderung dinilai) sebatas formalitas - seremonial semata. Tatkala kebutuhan akan dukungan rakyat dalam pilkada sedang berjalan, dramatisasi peran politik mulai dimainkan. Rerata kandidat mereposisi diri dari kalangan eksklusif menjadi inklusif atau bermula jauh dari pandangan dan kedekatan terhadap konstituen menjadi seolah-olah tak berjarak.

Dilema realitas ini kerap dipertunjukkan paska pilkada dilaksanakan. Upaya menagih komitmen politik juga terasa sulit sebab terbentur dengan prosedur yang harus dilalui, termasuk jamak dilakukan adalah berselimut dibalik ketentuan konstitusi. Kemaslahatan yang digaungkan menjadi cerita klasik yangg hampir selalu dan selalu terjadi. Meski ntah siapa yang salah, tetapi dalam sisi pemimpin terpilih dalam pilkada penting untuk lebih mempertunjukkan keberpihakan secara penuh kepada masyarakat.
Idealnya, para pemimpin baik secara politik maupun konstitusional memiliki tanggung jawab untuk mewujudkan kemaslahatan rakyat bersama dan merealisasikan kesejahteraan yang didengungkan. Kemaslahatan yang dilandasi oleh sikap untuk menunjukkan diri pada realitas politik, sosial dan ekonomi yang ada, dan bukan berpura-pura untuk sekedar membangun relasi kepercayaan dan kepentingan dengan masyarakat. Kebutuhan penting rakyat adalah bagaimana seluruh janji politik bisa menjadi landasan utama di dalam melakukan gerak langkah politik dan strategis pemimpin daerah.

Celakanya, dalam karakter politik dominan, rakyat jamak diperdaya dengan sekelebat janji kesejahteraan. Ketika sebelum menjadi pemimpin, suara-suara kritis berdaya transformatif terhadap sekelumit kejanggalan dalam tubuh bangsa menjadi suara yang idanh disampaian kepada rakyat. Rakyat selalu diimingiming dengan sejumlah janji dan paparan program yang begitu mentereng dan populis. Namun, ketika sudah berhasil merengkuh dayung kekuasaan, gema nyaring suara profetik-transformatif itu semakin hambar dan tak kedengaran lagi ${ }^{85}$.

Pilkada sebagai perhelatan politik, sejatinya merupakan sebuah

85. Joan Udu, Pilkada dan Harapan akan Lahirnya Pemimpin Ideal, Flores Post, 2015. 
panggung yang mempertunjukkan sebuah dramaturgi. Masalahnya, rakyat sebagai pemilik kedaulatan politik demokratis tidaklah membutuhkan dramaturgi yang memposisikan mereka hanya sekadar sebagai penonton pasif. Pilkada itu diidealkan harus adil, dan asas keadilan dimaksud bukan hanya dalam kerangka tidak ada pilih kasih dari pihak penyelenggara, tetapi juga harus adil dalam memperlakukan rakyat sebagai pemegang kedaulatan ${ }^{86}$.

Karena itu, pilkada tak hanya dipandang sebagai implementasi dari demokratisasi dan pengejawantahan hak konstitusional warga negara, tetapi bagaimana juga menjamin keberlakuan atas asas kedaulatan yang secara dominan menunt ut kepala daerah untuk bisa memenuhi segala harapan dan kepercayaan rakyat. Dinamika politik dan pemerintahan lokal akan membentuk geliatnya sendiri ketika seluruh proses politik dalam pilkada bisa menghasilkan kepala daerah yang bertanggung jawab, kompeten berkapasitas dan berintegritas.

\section{SIMPULAN DAN REKOMENDASI}

Moment um pilkada adalah sarana rakyat untuk secara bebas dan aktif menyeleksi siapapun yang dipercaya dan diyakini mampu memimpin daerah dengan segala konsekuensi politik yang mungkin akan terjadi. Dalam implementasi kedaulatan, rakyat berperan besar di dalam mewujudkan geliat dinamika politik dan pemerintahan lokal. Sebab, penentu tertinggi memang berada di tangan rakyat. Pada konteks itu pula, partisipasi rakyat menjadi instrumen penting guna menambatkan legitimasi secara layak bagi kepala daerah yang terpilih.

Meski secara kualitas demokrasi pilkada serentak perlu pembenahan, tapi upaya untuk memberi ruang partisipasi politik bagi rakyat tetap perlu diapresiasi. Ke depan, pembenahan paling krusial untuk dilakukan adalah membangun partisipasi aktif rakyat yang bukan hanya sekedar memilih, tetapi juga menghimpun kesadaran bersama akan pentingnya pemilihan bagi rakyat dan bagi masa depan daerah. Penekanan kepada partai politik juga harus lebih dituntut agarsecaraaktifdanberkesinambungan menjalankan fungsi-fungsi kepartaian, sehingga rakyat memahami secara komprehensif tentang pilihan politik.

\section{DAFTAR PUSTAKA}

Dahl, Robert A., 1971. Polyarchy: Opposition and Participation. New Haven and London. Yale University Press.

86. Mukhtar Sarman, op.cit, hal.8 
Dahl, Robert. 1999. Perihal Demokrasi: Menjelajahi Teori dan Praktek Demokrasi Secara Singkat. Jakarta. Yayasan Obor.

Djafar, TB. Massa. 2008. Demokratisasi, DPRD dan Penguatan Politik Lokal, Jurnal Poelitik, Vol. 1, No.1.

Gill, Guy S. Good. 1995. Pemilu Jurdil: Pengalaman dan Standar Internasional, PIRAC \& The Asia Foundation, Jakarta.

Hakim, Muhammad Zulfan Demokrasi dalam Pilkada Indonesia, artikel Jurnal, diakses dari Heywood, Andrey. 2014. Politics (4th edition). London. Palgrave Macmillan dan dialihbahasakan oleh Ahmad Lintang Lazuardi. Politik (edisi ke-4). Yogyakarta. Pustaka Pelajar.

Huntington, Samuel P dan Joan Nelson. 1994. Partisipasi Politik di Negara Berkembang. Jakarta. Rineka Cipta.

Iain, Mc. Lean. 1996. The Concise Dictionary of Politic. New York. Axford University Press.

Mats, Skoldberg dan Kaj Alvesson. 2000. Reflexive Methodology. London. Thousand Oaks,Sage Publication, New Delhi.

Sarman, Mukhtar. 2015. Pilkada Serentak: Quo Vadis Kedaulatan Rakyat. Program Magister Sains Administrasi Pembangunan Universitas Lambung Mangkurat. Banjarmasin.
Schumpeter, Joseph A. 19943. Capitalism, Socialism and Democracy. London. Allenand Unwin.

Stoker, Gerry. 1991. The Politics of Local Government ( $2^{\text {nd }}$ edition), London, Mcmillan.

Thaib, Dahlan. 1999. Kedaulatan Rakyat, Negara Hukum, dan Konstitusi. Yogyakarta. Liberty.

Udu, Joan. 2015. Pilkada dan Harapan akan Lahirnya Pemimpin Ideal, Flores Post.

http://www.kpu.go.id/index.php/post/ $\mathrm{read} / 2015 / 4101 / 810$-PasanganCalon-telah-Terdaft ar-dalamPilkada-Serentak-2015, diakses tanggal 1 Februari 2016, pukul 21.10 WIB.

http://www.bawaslu-dki.go. id/14/12/2015/menyoalpartisipasi-pemilih-pilkada/, diakses tanggal 1 Februari 2016, pukul 21.20 WIB.

http://repository.unhas.ac.id/ b $\begin{array}{lllllllll} & \mathrm{i} & \mathrm{t} & \mathrm{s} & \mathrm{t} & \mathrm{r} & \mathrm{e} & \mathrm{a} & \mathrm{m}\end{array}$ h andle/123456789/4068/ DEMOKRASI\%20DALAM\%20 P I L K A D A \% 20 D I \% 20 INDONESIA $\% 20 \% 28$ Jurnal $\% 20$ $\mathrm{H}$ u m a n i s \% 20 U N M \% 29. pdf? sequence $=1, \quad$ tanggal 8 Februari 2015, pukul 20.10 WIB. http://elisa.ugm.ac.id/user/archive/do wnload/32057/1 eca8113b230477 6be65f882f93e9009, diakses tanggal 8 April 2016, pukul 21.10 WIB. 